\title{
The Expanded Public Works Programme: Perspectives of direct beneficiaries
}

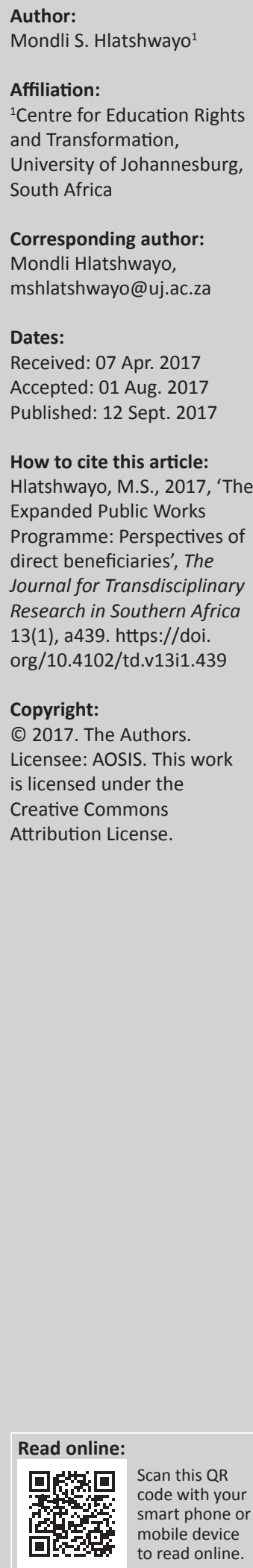

Scholarship on the Expanded Public Works Programme (EPWP) in South Africa tends to focus on quantitative evaluation to measure the progress made in the implementation of EPWP projects. The number of employment opportunities created by EPWP, demographic profiling, skills acquired by beneficiaries and training opportunities related to the Programme form the basis of typical statistical evaluations of it, but exclude comment by the workers who participate in its projects. Based on primary sources, including in-depth interviews, newspaper reports and internet sources, this article seeks to provide a qualitative review of the EPWP from the perspective of the beneficiaries of municipal EPWP projects. Various South African government sectors hire EPWP workers to provide local services such as cleaning and maintaining infrastructure, but the employment of these workers can still be regarded as precarious, in the sense that they have no job security, earn low wages and have no benefits such as medical aid or pension fund. The interviewees indicated that, although they appreciate the temporary employment opportunities provided by the EPWP, they also experience health and safety risks and lack the advantages of organised labour groupings. Their main disadvantage, however, is that they cannot access permanent employment, which offers better wages and concomitant benefits.

\section{Introduction}

By presenting and analysing the views and perspectives of workers employed in the Expanded Public Works Programme (EPWP), this article highlights key issues related to the ways in which the Programme and other government projects address the social and economic challenges facing South Africa. These issues should be debated by policymakers and investigated by researchers so they can help to view the EPWP beneficiaries as social agents, capable of playing a major role in an impartial assessment of government initiatives such as the EPWP.

In the South African context, especially in the post-apartheid era, those involved in the social sciences have initiated a number of projects to advance the development and expansion of research regarding the impact of government policies on various sections of the South African public, especially the economically disadvantaged (Bruce 2015; Langa 2015). The purpose of this article is to capture the voices of workers directly involved in EPWP projects. Because it is based on qualitative research, it is hoped that this study will be of use to policymakers in reviewing the implementation of the EPWP in order to improve the conditions of its workers. There is already some recognition by the South African government that the EPWP requires such policy reforms (Department of Public Works 2015).

The EPWP workers interviewed as part of this research pointed out that that they provided vital services to local, provincial and national government, mainly by cleaning and maintaining premises and infrastructure. The income they earned helped them to survive; they used their wages to purchase food and electricity and could begin to deal with other challenges that they and their families faced. However, they were of the opinion that the temporary nature of their jobs, the low wages they earned and the poor working conditions they were subjected to were issues that should be addressed by the government.

Before presenting the views and perspectives of the interviewees in more detail, this article reviews the existing literature on the EPWP, emphasising the need to include the voices and views of EPWP workers in the scholarly domain. This is followed by an account of how the relevant data were collected and analysed. This article then summarises responses to interview questions, in which EPWP workers express their views and perspectives regarding their conditions of work, wages and benefits. This is followed by a discussion of the themes that emerged from the 
interviews, from which conclusions are then drawn. This section also examines ways in which government policy has, indirectly, already responded to the problems described by the EPWP workers.

\section{Literature review: Absence of workers' voices and views}

Formally introduced in 2003, the EPWP can be traced back to the Reconstruction and Development Programme (RDP) implemented by South Africa's governing party, the African National Congress (ANC). The RDP viewed the EPWP as 'the key area where special measures to create jobs can link to building the economy and meeting basic needs ... in redressing apartheid-created infrastructural disparities' (ANC 1994:22). The EPWP thus had three functions: job creation, developing local infrastructure and the provision of basic services (ANC 1994).

The EPWP's job creation function had a double purpose: to create short-term employment and to alleviate poverty in the context of generalised unemployment among disadvantaged and marginalised citizens (Altman \& Hemson 2007; Mkhatshwa-Ngwenya 2016; Moeti 2014). Altman and Hemson (2007:5) further state that the EPWP 'aimed to provide work opportunities, training and a launch-pad for trainees into the labour market'.

In reviewing the literature on the EPWP, it is necessary to highlight its strengths and the notable gaps in scholarship relating to it. The literature can be divided into two main strands. The first stream of the literature tends to emphasise discussion of the targets, focusing on the number of workers absorbed by EPWP projects, as well as the training and demographics of EPWP workers (Altman \& Hemson 2007; Mkhatshwa-Ngwenya 2016; Moeti 2014). Although this quantitative aspect of the EPWP is crucial in assisting social scientists in understanding the reach of the EPWP, a limitation of this literature is that it tends to exclude the voices of EPWP workers, although these workers are the backbone of the EPWP as they do the actual work.

The second stream of the literature seeks to highlight the conditions of EPWP workers without providing a platform for them to articulate their views and issues (Samson 2007; Theron 2014), in spite of the fact that they have an important role to play in shaping policy and practice relating to their working conditions.

The South African government's National Development Plan (NDP) seeks to improve the living conditions of people of South Africa and to create a more equitable society by 2030 . The NDP further states that the 'triple challenge of unemployment, poverty and inequality' (National Planning Commission 2012:29) requires urgent attention if the fruits of democracy are to be enjoyed by all South Africans. The document emphasises the statistics pertaining to the EPWP. Among many other proposals, the NDP calls upon the government to 'broaden the expanded public works programme to cover 2 million fulltime equivalent jobs by 2020' (National Planning Commission 2012:29).

In assessing the EPWPs quantitatively, Altman and Hemson (2007) assert:

The EPWP is not far off its job creation target as originally framed. It has generated approximately 716,400 work opportunities in three years, as against a target of one million over five years. (p. 10)

In spite of this, these authors express the following reservation:

However, these are very short-term opportunities: if the jobs are translated into the equivalent of a full-time job (that is, 230 hours per year), the five-year target would be stated as 650,000 jobs versus 220,000 generated over three years. If compared to the larger unemployment problem, the targets were set at a low level and the overall contribution to reducing unemployment is small. (Altman \& Hemson 2007:5)

According to Samson (2015), who has conducted one of the most recent evaluations of the EPWP in the social sector, the minimum wage or stipend received by EPWP workers was supposed to be R70.59 per day in 2014. However, the EPWP of the Western Cape government paid R3000 per month, an amount that is R500 lower than the proposed national minimum wage. However, workers in the Western Cape were better paid than those in other provinces.

Samson (2015) also notes progress with regard to compliance with the sectoral determination of the Minister of Labour:

By 2013/2014 most programmes were compliant with these features of the MD (Ministerial Determination), as demonstrated by the average minimum wages reported in each programme. ... This represents important progress in providing income support to participants, many of whom were volunteers before the introduction of EPWP-SS (Social Sector). (p. 26)

Samson's research does not provide EPWP workers with a space to air their views and perceptions on the EPWP; instead, it relies on statistics. However, his contribution is valuable in the sense that it indicates that some progress has been made regarding a gradual improvement in compliance with the sectoral determination. It is necessary to acknowledge here the sterling contribution he and various other researchers have made to understanding the role and the impact of EPWPs statistically or quantitatively (Altman \& Hemson 2007; Phillips 2004; Samson 2015; Theron 2014). In their examination of the EPWP, these researchers raise a number of critical issues, ranging from the social and economic targets of the EPWP to labour relations. However, the quantitative literature on the EPWP tends to focus exclusively on targets, incomes earned by EPWP workers and the social and economic impact of the programmes (Altman \& Hemson 2007; Phillips 2004; Samson 2015). Although the quantitative data employed in these studies shed light on the impact of a policy on the workers, its target audience, social scientists, should also examine the impact of policy by listening to and engaging with those who benefit from programmes like the EPWP. 
The second strand of the literature is critical of the EPWP and views them as part of the state's austerity measures, which leads to the creation of a two-tier labour system in the public sector, comprising a tiny minority of permanent state employees with benefits and decent wages, and another layer, like the EPWP beneficiaries, who work under precarious conditions and earn very low wages (Jacobs 2015; Moyo 2013; Plaatjies \& Nicolaou-Manias 2005; Samson 2007).

Theron (2014) concurs that EPWP projects have created the work opportunities envisaged by those who conceptualised the programme. For example, Theron (2014:10) states that: 'between 1 April and 30 September 2012, the EPWP reported that it created 577575 work opportunities'. 'Work opportunities' are generally defined as 'temporary employment of between four to six month's duration'.

Theron (2014) notes that community care workers operating in the Cape Town municipality established a forum that began to challenge the precarious nature of their employment and their working conditions. Theron (2014:20) continues: 'Apart from job security, the issues affecting workers in nonstandard employment in the public sector are as various as those affecting any other category of vulnerable employee'. These issues include health and safety problems, low wages and a dearth of benefits like medical insurance and a pension fund. Although Theron (2014) has tried to introduce the voices of EPWP workers and their organisational responses in his work, the literature on EPWPs has tended not to examine conditions of work under the EPWPs by focusing on the views and voices of EPWP workers (Hemson 2015; Samson 2015). Because the workers have not been consulted, issues around their conditions of employment have remained unresolved to a large extent.

In fact, Chakwizira (2010) argues that the analysis and interrogation of the results of EPWP projects should go beyond quantitative data measuring the number of roads constructed and jobs created; it also requires a qualitative examination of the conditions of the workers involved in it. This is because, as this article argues, the South African Constitution and labour legislation are intended to progressively improve the lives of workers and of poor people in general, and to address and gradually eliminate social and economic inequalities (Bendix 2010).

In their research-based article entitled Listen to those who matter the most, the beneficiaries, Twersky et al. (2013) contend:

In bypassing the beneficiary as a source of information and experience, we deprive ourselves of insights into how we might do better-insights that are uniquely grounded in the day-to-day experiences of the very people the programs are created for. (p. 41)

The scholarly contribution of this article is therefore to go beyond the statistics and generalised impact assessments of the EPWP by engaging directly with the beneficiaries who perform the EPWP work that is implemented by the government at the grassroots level. This article is based on direct discussions with EPWP workers, who confirmed that violations of workers' rights occur, but also highlighted some economic benefits of EPWP employment.

To be more specific, the research presented here sought to solicit the views of EPWP workers, who were interviewed on the nature and form of their work, and their working conditions. The workers were also asked to articulate their views on how these could be improved in the future. The aim of asking these two related questions was to contribute to the literature on the EPWP by focusing on the working conditions of EPWP workers, from their own perspective.

\section{Research methodology}

The findings presented in this article are part of a wider research project on vulnerable workers, also referred to as 'precarious workers': those who earn low wages and have no security of employment, in five metropolitan and urban areas of South Africa. Twenty interviews were conducted with EPWP workers in Buffalo City, Ekurhuleni, Johannesburg, Vanderbijlpark and Mangaung. The data were then collated and analysed. To make sure that the interviewees were able to discuss issues freely, they were given the assurance that their names would not be revealed. An interview schedule was used that required interviewees to reflect broadly on their biographical details, work histories, experiences of working in the EPWP, and their views and perspectives on EPWP work. This was the main research tool for collecting their testimonies.

Although in-depth interviews are useful in giving interviewees a space to articulate their views and are commonly used in qualitative research (Cassell 2005), they cannot provide a complete account of the topic. This is because the interviewees might not wish to reveal all the details of their personal circumstances, or because of a fear of possible embarrassment or victimisation. In any case, it is not in the nature of human beings to remember every detail: memories are fallible. However, the interviews provided valuable information about the lived experiences of EPWP workers and addressed the lacunae in the literature which have been discussed.

According to Alsaawi (2014), combining different datacollection methods can help to overcome the limitations of interviews alone. In assembling relevant material, newspaper articles were useful sources of accurate data on events and on the views of EPWP workers, municipal authorities and government officials. Newspaper articles and internet sources confirmed that EPWP workers earned low wages in parts of South Africa. Besides the issues that were targeted, they also discussed the central question of the lack of job security in EPWP work. Newspapers and internet sources were not cited in this article, the aim of which was to highlight the voices of the interviewees, but such sources contributed towards an understanding of the environment in which EPWP workers operate and informed the formulation of the interview questions. 
A theme-based approach was employed in analysing the data: this involved a close reading of the interview transcripts in order to identify common themes relating to the research questions (Fereday \& Muir-Cochrane 2006). The main question addressed by the research was as follows: 'What are the views, experiences, and perceptions of EPWP workers on their recruitment, wages and working conditions?' The study sought to understand the working conditions of EPWP workers through the lens of the actual EPWP employees.

\section{Findings}

The themes that emerged from the interviews included the process of recruiting workers for EPWP projects in the interviewees' home areas, their reflections on the wages and benefits of EPWP workers and the aspirations of EPWP workers, which entailed advocating for permanent employment with job security and benefits.

\section{The recruitment process}

Based on the interviews, it appeared that being a member of the ANC, participating in its political activities and in ward committees was rewarded with access to work opportunities in the form of employment in EPWP projects. However, not all EPWP workers ascribed their employment to political activism and membership of the ANC.

A single parent who has always worked as a precarious worker described how she was recruited into an EPWP project in Bloemfontein:

'I was recruited by a ward committee member. We used to attend ANC meetings and were part of the ANC's door-to-door campaigns. ... The ANC has taught me a lot and it has helped me.' (Interviewee 1, Bloemfontein, 04 June 2016)

Another respondent, who recruited the first interviewee and her sister, is an ANC member and a member of the ward committee. He said:

'In terms of my political affiliation, I am a member of ANC. I joined it eight or nine years ago. Before that I was a member of the South African Civic Organisation (SANCO). ... I am a ward committee member.' (Interviewee 2, Bloemfontein, 04 June 2016)

Interviewee 2 indicated that after he was retrenched by his company, which relocated to Durban, he was unemployed for five years. He joined the EPWP as a general worker in 2016 and later became a supervisor, which gave him the authority to recruit and supervise other workers employed in the same project.

Another EPWP worker, a single parent of two children, who was based in East London's Duncan Village, was an ANC cadre involved in campaigning for the party in the 2016 local government elections. Her sister, who helped her find an employment opportunity in the EPWP, is another ANC cadre and a councillor in the area. When asked about how she became employed in the EPWP, she responded:
'My sister asked me if I wanted an EPWP job. I said yes and I got the job. Besides working as an EPWP worker, I also do campaigning for the ANC. We won this ward.' (Interviewee 3, East London, 04 August 2016)

These interviews reveal what can be regarded as localised cadre deployment in the context of EPWP work. Being part of the local ANC and participating in campaigns that advance its interests in these instances led to being rewarded with EPWP employment opportunities. The deployment of cadres as a reward for loyalty to the ANC does not occur only in the upper echelons of the government and state entities, but is also practised when placing people in poorly paid positions in the EPWP. Based on the interviews conducted with EPWP workers, it can be concluded that this 'cadre deployment from below' involves awarding jobs to those who are part of local ANC structures. Unlike other forms of cadre deployment, it involves low wages and no employment benefits. However, such workers do earn minimal income, which is crucial in the context of high unemployment and poverty in their communities.

\section{The nature of the Expanded Public Works Programme work}

One of the interview questions sought to develop an understanding of the nature and forms of EPWP work. The aim was to understand whether or not there were safety concerns involved in EPWP work. The respondent from Duncan Village (quoted earlier) spoke about the difficulties of the work they are doing as employees of an EPWP project in East London:

'We clean the drainage system, sweep and clean venues of national and provincial events. This work is hard. Sometimes we work in bushy areas, and one of our fellow workers was bitten by an insect. She had to go to a clinic, and had to pay for medical treatment out of her own pocket.'(Interviewee 3, East London, 04 August 2016)

However, the same worker indicated that a new project, initiated in the Buffalo City in 2016, did take some health and safety issues into consideration. The worker said:

'This new project takes care our health care issues. We do get safety boots, overalls, and gloves. There is an improvement regarding health and safety issues.' (Interviewee 3, East London, 04 August 2016)

A female EPWP employee working for the 'clean city' project in the Ekurhuleni municipality commented:

'We make sure that the city is clean. We sweep and pick up waste.' (Interviewee 4, Germiston, 20 September 2016)

She elaborated on the difficulties involved in her work and on issues of health and safety:

'We do not have always have health and safety clothing. This then exposes us to sicknesses and diseases.' (Interviewee 4, Germiston, 20 September 2016)

A male EPWP worker who maintains roads in Johannesburg was also concerned about health and safety issues. He said: 
'We do not have enough protective clothing and tools. The employers do not respect our rights as workers. Health and safety is one of our major concerns.' (Interviewee 5, Johannesburg, 18 September 2016)

Besides the type of work and health and safety issues, EPWP workers were also asked about the number of days they were employed. This was relevant in the sense that EPWP work tends to be irregular and workers do not always have a fiveday working week like other permanent workers. Unlike the conditions in East London, where the interviewee claimed they worked five days a week doing intense manual work, EPWP workers in Bloemfontein worked for only two days a week. One of the EPWP workers explained:

'I started working in the EPWP project in 2016. We work from 8 am to $4 \mathrm{pm}$....We sweep the streets and we have to make sure that the township is clean.' (Interviewee 6, Bloemfontein, 04 June 2016)

Based on these accounts by EPWP workers, it can be argued that the interviewees provided crucial public services, ranging from cleaning the parks, streets and public buildings to maintaining road infrastructure. However, in the case of East London and Germiston, health and safety concerns seem to have been neglected by the authorities managing the EPWP work. This increased the vulnerability of the workers as they were exposed to injuries and infections. The number of working days was not standardised: some interviewees worked for five days and others for two days a week. There was also variation in the intensity of the work, with some workers complaining about carrying huge workloads for five days a week.

\section{Wages and benefits}

Wages are obviously crucial to EPWP workers, enabling them to purchase essentials such as food and electricity. The testimonies of the workers revealed two interesting trends. First, the EPWP workers appreciated the fact that they were earning an income from the state, which enabled them to start meeting livelihood challenges and support their households. In some households, EPWP wages helped to supplement other sources of income, including social grants and wages earned by other family members. The money the EPWP workers earned made a huge difference in the context of unemployment and generalised poverty. Second, in some cases, workers felt strongly that the wages for EPWP work were much too low, as they had to deal with the rising cost of living.

\section{An EPWP worker in Bloemfontein remarked:}

\begin{abstract}
'We were told that we would work two days per week. We were earning R697 after UIF deductions per month. My sister is also an EPWP worker and we also receive a state grant. This has helped me a lot and we were able to build a room and renovate a house.' (Interviewee 5, Bloemfontein, 04 June 2016)
\end{abstract}

The interviewee quoted above worked in an EPWP project with her sister, and they also receive state grants for single parents. Both these sources of income helped them meet basic needs such as food, water and electricity, and they were also able to add a room to their two-roomed house. Their combined incomes, although small, enabled this family to survive in an environment characterised by generalised poverty. It is therefore clear that the state made provision for this family in the form of EPWP work and state grants.

According to another interviewee who is 25 years old and lives with his mother in a township in Germiston, EPWP work has helped him deal with his financial problems. The interviewee commented:

'I come from a family of four and we live with just our mother. I matriculated last year, but couldn't further my studies. There was no money for tertiary education. I am a street sweeper working under the local municipality. The working conditions are okay. I get paid R2 200 monthly. Before that, things financially were bad. I used to borrow money from a mashonisa (loan shark). I am now able to contribute to sustaining my family. I help my mother. I am doing just fine and that has to with my EPWP job.' (Interviewee 6, Germiston, 20 September 2016)

Another worker also employed working on the 'clean city' campaign in Germiston lives in a shack in an informal settlement. He spoke about earning a low wage and having to deal with service delivery problems such as access to electricity and water. The worker reflected:

'I live in a shack and I earn R500 a week. Life is hard. We are earning very low wages. I have been part of been part of community protests which sought to deal with service delivery problems my community. These protests help us access electricity. I also supplement my income by selling recycled waste.' (Interview 7, Germiston, 20 September 2016)

An EPWP worker in Orange Farm, a township south of Johannesburg, was employed by the city of Johannesburg to clean a local school. She raised the issue of the lack of benefits as a problem inherent in EPWP employment:

'As I'm saying that we work here we don't have benefits but
there are people who work here doing the work we are doing.
They have benefits but at the end of the day you find that people
who work hard it's us. Other workers who look after schools
tend to have better wages and benefits, but those employed
under EPWP have none of that. The people who work here at
school don't do any work at all; we are the ones who work.'
(Interviewee 8, Johannesburg, 13 January 2017)

Based on these testimonies, it can be argued that the EPWP workers used their wages to supplement the total incomes of their households. Other sources of income included social grants and selling recycled material. In these instances, EPWP work became crucial for maintaining and sustaining families, especially in the context of generalised poverty and unemployment.

These positive aspects do not eliminate the fact that work conducted by EPWP workers was devalued and that, by their own accounts, they earned low wages and had no other benefits. Their situation was complicated by the fact that they did not have job security. The EPWP workers did not have a 
sense of belonging as they were exposed to bad working conditions and lacked recognition for their labours. They did not participate in the same activities as permanent workers, confirming the notion of a two-tier labour market in the public sector. It should also be noted that in the past, these EPWP jobs were performed by permanent workers who had benefits and were employed by municipalities.

\section{Organisational rights}

South African workers are supposed to enjoy the right to belong to a union that advances their collective rights as workers. Unions are important in the sense that they can help workers improve their working conditions and wages. In this study, EPWP employees were asked whether they belonged to unions. The worker based in Germiston said:

'We have too many problems. I am a casual worker. I have not job security. Health and safety is compromised. We do not have a union. No union has approached us. I guess that has to do with the fact that we are not permanent workers.' (Interviewee 7 , Germiston, 20 September 2016)

Although all workers have the right to organise and form unions and associations that advance their interests, fear of victimisation seemed to be one of the factors contributing to EPWP workers' lack of unionisation. The EPWP worker in Orange Farm quoted earlier, voiced concerns about intimidation, which took place when she and her co-workers attempted to organise themselves. She commented:

'We have nothing. We have no shop stewards who are supposed to represent us. The shop stewards are supposed to help us get paid decent wages. Whenever workers start having meetings to discuss such things, there is someone who goes and tells our supervisor and no one wants to get fired.' (Interviewee 8, Johannesburg, 13 January 2017)

Despite fear of victimisation, workers in Orange Farm went on a strike last year, demanding re-employment. One informant said:

'It was during the time that they had stopped us; it was during the time that others went out to fight for us to come back when the employer was saying they would hire other people. The people here said you cannot hire other people when you have fired other people for no reason. They have to come back first and then you can add more people.' (Interviewee 9, Johannesburg, 11 January 2017)

EPWP workers tended to be caught between a rock and a hard place: trade unions did not recruit them; they were not seen as part of the workforce as they were not permanent employees and were easily got rid of, yet they performed work such as cleaning buildings, which helped to maintain government institutions and infrastructure. This indicates that the current union model is currently too rigid and does not take into account the existence of precarious workers, who have flexible employment but need protection so as to advance their rights and interests. In order to fulfil its role of representing the interests of all citizens, government needs to create platforms within its workplaces where
EPWP workers can air their concerns without fear of harassment or victimisation.

\section{The desire for permanent employment}

Although the EPWP projects helped workers earn some income to support themselves and their families, the uncertainties of this form of employment were a source of concern. In some instances, projects were halted because of budgetary problems within local municipalities. In others, local elections led to the cancellation or delay of projects, as incoming councillors implemented different plans based on the promises they had made to supporters; this was a common occurrence in 2016. In such situations, EPWP workers were left in limbo. The EPWP worker in Bloemfontein (quoted earlier) reflected on the uncertainties faced by EPWP workers:

'The project was stopped because they said that they were still waiting for the money from the municipality, and this is now happening for the second time, because in 2015 in November they stopped it and in January 2016 we were not operational, and this had posed huge challenges because of my wife not working. The frustration is that one is not sure whether the incoming ward councillor will ensure that the project continues or not.' (Interviewee 1, Bloemfontein, 04 June 2016)

Another female EPWP worker from Bloemfontein also expressed uncertainty about the future of her work. She said:

'I am not sure about my future, because the contract comes to an end at the end of August [2016]. We can see that the places are dirty and there is a need for permanent employees who can clean all these facilities. I do not understand why they are not employing us. I started working in the EPWP since March 2016 and my contract will end in August 2016.' (Interviewee 3, East London, 04 August 2016)

An EPWP worker employed by the Vanderbijlpark municipality expressed a sense of insecurity associated with the fact that jobs often depended on relationships with a local councillor. The worker commented:

'I am not sure whether my contract will be renewed or not. It should come to an end at the end of March 2017. That is what I signed for. I am really not sure if I'll get another contract again. I also heard that our councillor seems to be the one causing this uncertainty. The councillor wants to get rid of some EPWP workers. Our coordinator indicated that we could sign new contracts, just like the other EPWP workers, but our councillor has other plans that are not being shared with us. We signed three-month contracts which were extended to another three months. They told us that this is not a permanent job, and we should give others a chance. I do not think I can apply for credit because I do not have a permanent job.' (Interview 10, Vanderbijlpark, 03 March 2017)

The short-term nature of EPWP jobs was a source of anxiety among the EPWP workers interviewed for this research. The worker above also mentioned her inability to get credit because of her low income and job insecurity, which was a common experience among these workers. EPWP workers were unable to get even very small amounts of credit, so in some instances they were forced to turn to loan sharks, who 
charged them exorbitant interest, thus increasing their vulnerability and their financial problems.

To address the insecurity and vulnerability associated with the short-term nature of EWP contracts, another EPWP worker based in Orange Farm suggested the following:

'What needs to be done is that we must be permanent, we must have clock cards and then we must have ... that which says what you supposed to do during your working day.' (Interviewee 11, Johannesburg, 13 January 2017)

An EPWP worker in Bloemfontein (quoted earlier) spoke about her desire for permanent employment:

'Finally, I wish I can get a better job. It is my wish. My colleagues in the EPWP desire a decent wage increase. We are about forty workers of which only seven are males. They [EPWP workers] also want permanent jobs and benefits.' (Interviewee 1, Bloemfontein, 04 June 2016)

\section{Discussion and conclusion}

One of the first issues raised by this research is the partybased selection process for EPWP projects. The interviewees indicated that being active in the local ANC branch or party structure translated into being part of the EPWP. This is unacceptable as these employment opportunities are supposed to be available for all South Africans. During a parliamentary debate on the EPWPs in 2016, the Deputy Minister of Public Works, Jeremy Cronin, suggested that a lottery system, as used in the Western Cape, should be used to select EPWP workers. The need for community monitoring and evaluation was also emphasised by the deputy minister (Bega 2014).

In response to complaints about nepotism in the recruitment processes of the EPWP, as well as its working hours and working conditions, the Department of Public Works in 2015 issued guidelines for the regulation of EPWP projects. They included the following:

'Workers are recruited through a fair and transparent process. The selection of each worker must be done based on a clear set of criteria and should follow a fair and transparent process to minimize patronage and abuse.' (Department of Public Works 2015:2)

According to the deputy minister, communities are meant to take charge and be able to influence the running of the EPWP projects. It is hoped that this article will add another critical voice with regard to the workings of the EPWP and that communities where EPWP workers are engaged can make sure that the projects help to facilitate the development envisaged by the RDP.

This article in intended to fill the gap in literature concerned with implementation of the EPWP, which often fails to take into account the voices and views of the beneficiaries who carry out the actual work. The article has demonstrated that there are three related problems implicit in the EPWP, namely the short-term nature of the projects, the health and safety concerns associated with them, and the low incomes earned by workers. The perspectives expressed by the EPWP workers indicated that the workers wanted security in the form of permanent employment, which would entitle them to the benefits enjoyed by permanent workers.

It could be argued that their aspirations were consistent with the NDP, which calls for permanent employment of EPWP workers in the long term and argues that EPWP jobs should be converted into full-time employment to minimise the high unemployment rate (National Planning Commission 2012). The EPWP workers' desire for permanent jobs was also in keeping with the RDP, which states that the EPWP ought not 'abuse labour standards nor create unfair competition within sectors of the economy' (ANC 1994:23).

Although the NDP plans to convertEPWP'workopportunities' into permanent jobs, it seems that the current temporary nature of EPWP opportunities will not change in the foreseeable future. In his medium-term budget speech, the former Minister of Finance, Pravin Gordhan, stated that about 25000 jobs would have to be cut to contain the expenditure of state departments. This would be done through attrition, meaning that staff shortages would continue to be one of the challenges facing local government and the state in general. The minister further indicated that the government planned to raise revenue through tax, by reducing the number of state employees and by reducing the budgets of municipalities and provincial governments (Paton 2016). The measures that will be introduced by the new Finance Minister, Malusi Gigaba, regarding fiscal policy remain to be seen.

From the interviews, it can be inferred that what complicated matters for the EPWP workers canvassed for this study was that they did not have a voice in the workplace. This had to do with fear of victimisation: their concern was that if they started organising workers' associations or forming committees or unions, management might dismiss them. The problem was compounded by the fact that there were divisions between permanent workers, who tended to belong to unions, and EPWP employees who were not unionised. This finding indicates that managers in the public sector and in local government need to find ways of making sure there are platforms for EPWP workers to air their views with regard to workplace issues and working conditions. Concerns around health and safety could then be resolved quickly, as they do not require large expenditure.

One of the main contributions of this research has been to give EPWP workers a voice that tended to be absent in the evaluations of the EPWP. Clearly, EPWP workers cannot be treated as a monolithic group: there were interviewees who accepted their conditions of work and felt that the EPWP has contributed immensely to their livelihoods, but there were also those who voiced their concerns about working conditions and unfair treatment in the workplace, and who expressed their desire for permanent employment, which would help to reduce their social and economic vulnerability by providing them with job security, better wages and employee benefits. 
Consistent with the findings of this study, according to Hemson (2015:22), the international experience of EPWP structures points to the fact that these programmes are 'only effective as a temporary safety net'. This statement could be interpreted as calling for medium- and long-term strategies to deal with poverty and unemployment. The current EPWP will have to be supported with permanent budgets and other government measures, and should also be directly involved in adding value creation and generating income if it is to be a permanent option. These concluding remarks now relate more directly to the topic and to beneficiaries' statements which propose to make EPWP to be sustainable as a mechanism for job creation.

\section{Acknowledgements Competing interests}

The author declares that he has no financial or personal relationships which may have inappropriately influenced him in writing this article.

\section{References}

African National Congress (ANC), 1994, The reconstruction and developmen programme: A policy framework, Umanyano Publications, Johannesburg.

Alsaawi, A., 2014, 'A critical review of qualitative interviews', European Journal of Business and Social Sciences 3(4), 149-156. https://doi.org/10.2139/ssrn.2819536

Altman, M., \& Hemson, D., 2007, The role of Expanded Public Works Programmes in halving Unemployment, HSRC Press, Pretoria, viewed 03 June 2017, from http:// repository.hsrc.ac.za/bitstream/handle/20.500.11910/5819/4852_Altman Roleofexpandedpublicworks.pdf?sequence $=1$

Bega, M., 2014, 'Public Works to cut out patronage in EPWP', Citizen, 9 September 2014 viewed 03 June 2017, from http://citizen.co.za/news/news-national/ 240192/public-works-cut-patronage-epwp

Bendix, S., 2010, Industrial relations in South Africa, Juta and Company Ltd., Johannesburg.

Bruce, D., 2015, The good, the better and the best: How the Community Work Programme can reach its full potential as an instrument of community development in South Africa, Centre for the Study of Violence and Reconciliation, Johannesburg.

Cassell, C., 2005, 'Creating the interviewer: Identity work in the management research process', Qualitative Research 5(2), 167-179. https://doi.org/10.1177/14687941 05050833

Chakwizira, J., 2010, Stretching the concept of the expanded public works programme in South Africa: Tracing the footsteps and gauging the footprints-the unfinished rural development transformation story, viewed 07 August 2017, from http:// researchspace.csir.co.za/dspace/handle/10204/4402
Department of Public Works, 2015, Guidelines for the implementation of labour-intensive infrastructure projects under the Expanded Public Works Programme (EPWP), 3rd edn., Department of Public Works, Pretoria, viewed 03 June 2017, from http://www. epwp.gov.za/documents/Infrastructure/Infrastructure $\% 20$ incentive $\% 20$ manual/2015/EPWP_Infrastructure_Guidelines_3rd_Edition_June2015.pdf

Fereday, J., \& Muir-Cochrane, E., 2006, 'Demonstrating rigor using thematic analysis: A hybrid approach of inductive and deductive coding and theme development' International Journal of Qualitative Methods 5(1), 80-92. https://doi. org/10.1177/160940690600500107

Hemson, D., 2015, Mid-term review of the Expanded Public Works Programme: Component 3: Analysis and review, Human Science Research Council, Pretoria.

Jacobs, M., 2015, 'Youth unemployment in South Africa: A critique of current economic policies', master's thesis, University of Campinas, Campinas, Brazil.

Langa, M., 2015, 'Impact of the Community Work Programme (CWP) on violence in Orange Farm', research report, Centre for the Study of Violence and Reconciliation, Johannesburg, viewed 03 June 2017, from https://idl-bnc-idrc.dspacedirect.org/ handle/10625/55267

Mkhatshwa-Ngwenya, E.N.M., 2016, 'Implementation of the Expanded Public Works Programme (EPWP) in South Africa (2004-2014)', doctoral dissertation, University of South Africa, Pretoria.

Moeti, L., 2014, 'Towards the effective implementation of the expanded public works programme in South African municipalities: A case study of the City of Tshwane metropolitan municipality', master's thesis, University of South Africa, Pretoria, viewed 03 June 2017, from http://uir.unisa.ac.za/bitstream/handle/10500/13634/ dissertation_moeti_l.pdf?sequence=1\&isAllowed $=y$

Moyo, M., 2013, How effective is EPWP employment in enhancing the employability of participants once they exit these programmes? The case of the Modimola Integrated Expanded Public Works Programme (EPWP), North West Province, Department of Sociology Research Report, University of the Witwatersrand, Johannesburg, viewed 03 June 2017, from http://146.141.12.21/bitstream/handle/10539/12993/MA\%20 Thesis_Final $\% 20 \%$ 20Submission_18\%20June_2013.pdf?sequence $=1$

National Planning Commission, 2012, National Development Plan 2030: Our futuremake it work, National Planning Commission, Pretoria.

Paton, C., 2016, 'South Africa Budget - Higher taxes and public sector job cuts on cards', Business Day Live, viewed 03 June 2017, from https:// africajournalismtheworld.com/2016/10/27/south-africa-budget-higher-taxesand-public-sector-job-cuts-on-cards/

Phillips, S., 2004, 'The Expanded Public Works Programme: Overcoming underdevelopment in South Africa's second economy', paper presented at UNDP, HSRC and DBSA Conference, 29 October 2004, Pretoria, South Africa.

Plaatjies, D. \& Nicolaou-Manias, K., 2005, Budgeting for job creation in social welfare services - Exploring EPWP opportunities, Human Sciences Research Council, Pretoria, viewed 03 June 2017, from file:///C:/Users/Craig/Downloads/4254_ Plaatjies_Bugetingforjobcreation.pdf

Samson, M., 2007, 'When public works programmes create "Second Economy" conditions', Africanus 37(2), 244-256.

Samson, M., 2015, Implementation evaluation of EPWP in the social sector: Phase Two (2009/10 - 2013/14): Final summary report on implementation evaluation of EPWP social sector Phase Two, 8 June 2015, Department of Performance Monitoring and Evaluation, Pretoria, viewed 03 June 2017, from http:// evaluations.dpme.gov.za/evaluations/508

Theron, J., 2014, Non-standard work arrangements in the public sector: The case of South Africa, International Labour Office, Geneva, viewed 03 June 2017, from http://ilo.org/wcmsp5/groups/public/---ed_dialogue/---sector/documents/ publication/wcms_310221.pdf

Twersky, F., Buchanan, P. \& Threlfall, V., 2013, Listening to those who matter most, the beneficiaries, Stanford Social Innovation Review, viewed 03 June 2017, from https:// ssir.org/articles/entry/listening_to_those_who_matter_most_the_beneficiaries 